\title{
Lactational response of early-lactation Holstein cows fed starch or floury corn silage
}

\author{
Ishwary P. Acharya ${ }^{1}$ and David P. Casper ${ }^{2 *}$ (1) \\ ${ }^{1}$ Kay Dee Feed LLC, 1919 Grand Avenue, Sioux City, IA 51106 \\ ${ }^{2}$ Casper's Calf Ranch, 4890 West Lily Creek Road, Freeport, IL 61032
}

\begin{abstract}
The study objective was to evaluate the lactational performance of early-lactation dairy cows fed a total mixed ration (TMR) based on corn silage produced from a standard starch hybrid compared with 2 floury starch hybrids. Twenty-one (6 primiparous and 21 multiparous) high-producing, early-lactation Holstein cows were blocked by calving date and parity and randomly assigned to 1 of 3 experimental corn silages from wk 4 through wk 12 postpartum using a randomized complete block design with wk 3 as a covariate. The Dekalb blend (STA; Monsanto Company, St. Louis, MO), Masters Choice 527 ( $\mathrm{LF}_{1}$; Masters Choice, Anna, IL), and Masters Choice $5250\left(\mathrm{LF}_{2}\right)$ treatments were planted and harvested as corn silage using a kernel processor silage harvester, inoculated, and ensiled in individual Ag-Bags (Ag-Bag, St. Nazianz, WI). The TMR were formulated to be isonitrogenous at $17.5 \%$ crude protein consisting of $15.9 \%$ alfalfa hay, $35.1 \%$ concentrate mix, and $48 \%$ of the respective experimental corn silage on a dry matter basis. Crude protein content of STA and $\mathrm{LF}_{2}$ was lower than $\mathrm{LF}_{1}$ corn silage. Starch content was higher for STA compared with $\mathrm{LF}_{1}$ and $\mathrm{LF}_{2}$ silage. The TMR digestible fiber (neutral detergent fiber) concentration was lower for STA than $\mathrm{LF}_{1}$ and $\mathrm{LF}_{2}$ (14.0, 15.5, and $17.9 \%$ dry matter for STA, $\mathrm{LF}_{1}$, and $\mathrm{LF}_{2}$, respectively). Growing crop year affected corn silage vomitoxin $(0.60,1.45$, and $1.56 \mathrm{mg} / \mathrm{kg})$ concentrations, which may have affected lactational performance as STA corn silage was from 2013, whereas $L_{1}$ and $L_{2}$ were from the 2012 crop year. Dry matter intake (22.9, 23.5 , and $22.4 \mathrm{~kg} / \mathrm{d}$ ), milk yield $(35.6,34.8$, and 36.1 $\mathrm{kg} / \mathrm{d}), 3.5 \%$ fat-corrected milk yield $(38.7,36.5$, and $37.6 \mathrm{~kg} / \mathrm{d})$, energy-corrected milk yield $(38.2,36.1$, and $38.1 \mathrm{~kg} / \mathrm{d})$, feed efficiency $(1.79,1.61$, and $1.67 \mathrm{~kg} / \mathrm{kg}$; $3.5 \%$ fat-corrected milk/dry matter intake), milk fat $(4.17,3.94$, and $3.71 \%)$, milk protein $(3.12,3.09$, and
\end{abstract}

Received April 8, 2019.

Accepted January 28, 2020.

*Corresponding author: david.casper10@jcwifi.com
$3.03 \%)$, lactose $(4.93,4.92$, and $4.92 \%)$, solids-not-fat $(8.96,8.92$, and $8.85 \%)$, body weight change $(-0.10$, -0.06 , and $-0.08 \mathrm{~kg} / \mathrm{d}$ ), and body condition score change $(-0.05,-0.04$, and -0.05 score/d) were similar for early-lactation dairy cows fed all corn silage hybrids. Lower ruminal $\mathrm{pH}$ and acetate along with higher propionate molar percentages were reported for cows fed STA compared with cows fed $\mathrm{LF}_{1}$ and $\mathrm{LF}_{2}$. Earlylactation dairy cows fed a corn silage with lower starch and higher digestible fiber concentrations resulted in similar milk production compared with cows fed higher starch and lower digestible fiber concentrations.

Key words: corn silage, corn hybrid, high-producing dairy cow

\section{INTRODUCTION}

Whole-plant corn harvested as corn silage is a key forage component in many TMR fed to lactating dairy cows and continues to be a valuable and economical nutrient source (Ferraretto and Shaver, 2015). Corn silage is normally a high-energy forage with high yield potential on a per hectare basis compared with other forage crops. Various types of seed corn hybrids are available for growing and harvesting corn silage for feeding dairy cattle including waxy, high lysine, brown midrib (BMR), high oil, and leafy hybrids. Continuous selection of seed corn hybrids for corn silage has increasingly focused on improving NDF digestibility in addition to high grain content and overall DM yield (Nennich et al., 2003). A survey of the published literature found several studies that compared different corn silage hybrids on dairy cattle performance (Barriere et al., 1995; Oba and Allen, 1999; Kuehn et al., 1999; Bal et al., 2000; Ballard et al., 2001; Thomas et al., 2001; Clark et al., 2002; Ferraretto and Shaver, 2015). The BMR trait has consistently demonstrated an improvement in milk production (Oba and Allen, 1999; Bal et al., 2000; Ballard et al., 2001; Ferraretto and Shaver, 2015) among the evaluated corn silage hybrids. The leafy gene results in a corn plant with 8 or more leaves about the top ear that are lower in lignin with 
thicker, more digestible stalks, and the starch structure is more floury than vitreous. Most studies have shown little or no changes in milk yield when leafy corn silage hybrids were fed to lactating dairy cows (Kuehn et al., 1999; Bal et al., 2000; Ballard et al., 2001). However, research conducted by Thomas et al. (2001) and Clark et al. (2002) reported higher milk production while feeding leafy corn silage hybrids compared with conventional corn silage hybrids. The feeding of leafy corn silage hybrids in the TMR to dairy cows often resulted in similar DMI compared with the TMR containing conventional corn hybrids (Kuehn et al., 1999; Bal et al., 2000; Thomas et al., 2001; Ferraretto and Shaver, 2015). However, Ballard et al. (2001) and Clark et al. (2002) reported higher DMI by lactating dairy cows when offered a leafy corn silage hybrid compared with a conventional corn silage hybrid.

Although past research has not demonstrated a consistent response in milk production, DMI, or both from feeding a particular seed corn silage hybrid, new seed corn silage hybrids are introduced every year in the marketplace. With the release of new seed corn hybrids, it is essential to evaluate their agronomic traits, as well as their response to maintain or enhance dairy cattle performance. Masters Choice (Anna, IL) has developed MC $527\left(\mathbf{L F}_{\mathbf{1}}\right)$ and $\mathrm{MC} 5250\left(\mathbf{L F}_{\mathbf{2}}\right)$ as 2 new seed corn silage hybrids that have a floury starch structure (Casper et al., 2017) and higher digestible fiber compared with traditional seed corn hybrids that are high in flinty starch and lower digestible fiber (Kleinjan et al., 2017). These seed corn hybrids have demonstrated increased corn silage yield, higher sugar concentrations, higher digestible fiber, and greater starch digestibilities (Kleinjan et al., 2017) compared with standard silage hybrids, which is speculated to an altered ratio of ether and ester linkages among lignin and fiber carbohydrates (Raffrenato et al., 2017). We hypothesized that feeding these 2 new seed corn silage hybrids $\left(\mathrm{LF}_{1}\right.$ and $\left.\mathrm{LF}_{2}\right)$ will supply more digestible energy as fiber and starch to enhance milk production compared with feeding a conventional starch corn silage hybrid. Therefore, the study objectives were to evaluate 2 floury corn hybrids, MC $527\left(\mathrm{LF}_{1}\right)$ and $\mathrm{MC} 5250\left(\mathrm{LF}_{2}\right)$, harvested for corn silage against conventional corn silage hybrid (STA) silage for nutrient composition, DMI, digestibility, and lactational performance of early-lactation dairy cows.

\section{MATERIALS AND METHODS}

\section{Corn Planting, Harvest, and Corn Silage Production}

Three different corn silage hybrids, STA (a blend of Dekalb Brand Seed including DKC48-12 RIB Brand Blend, DKC 52-29 RIB Brand Blend, and DKC 53-78
RIB Brand Blend, Monsanto Company, St. Louis, MO), MC $527\left(\mathrm{LF}_{1} ; 105\right.$ d maturity, Masters Choice Seed Corn), and $\mathrm{MC} 5250\left(\mathrm{LF}_{2} ; 102 \mathrm{~d}\right.$ maturity, Masters Choice Seed Corn), were planted at the South Dakota State University Dairy Research and Training Facility in Brookings according to their recommended seeding rates of $86,487 /$ ha and common agronomic practices. Fields were fertilized according to soil report recommendations and cultivated before planting. The $\mathrm{LF}_{1}$ and $\mathrm{LF}_{2}$ corn silage hybrids were grown and harvested during the 2012 crop year and STA corn silage was grown and harvested during the 2013 crop year. Corn silage was harvested at recommended maturity days of respective experimental varieties with a John Deere 6750 self-propelled forage harvester (John Deere, Moline, IL) set to a $1.9 \mathrm{~cm}$ theoretical length of cut with a kernel processor. After harvesting, corn silage was treated with Lactobacillus inoculant (Silo-King Plus, Agri-King Inc., Fulton, IL), ensiled in an Ag-Bag (AgBag, St. Nazianz, WI), and allowed to ferment followed by storage until fed. The storage times were approximately 4, 14, and 14 mo for STA, $\mathrm{LF}_{1}$, and $\mathrm{LF}_{2}$ corn silages, respectively.

\section{Lactating Dairy Cows, Rations, and Experimental Design}

This lactation study was conducted at the Dairy Research and Training Facility during the winter of 2013-2014. All lactating dairy cows were cared for and managed according to South Dakota State University Institutional Animal Care and Usage Committee recommendations. Cows were housed in a freestall barn and fed a covariate diet (control starch) as a TMR immediately after calving using the Calan Broadbent feeder door and box system (American Calan Inc., Northwood, NH). Cows remained on the covariate ration from calving through the third week postpartum, after which they were randomly assigned to 1 of 3 dietary treatments if they were healthy and normal (i.e., no transition problems). Cows were blocked by calving date and parity using a randomized complete block design. Thirty (9 primiparous and 21 multiparous) high-producing, early-lactation Holstein cows were randomly selected and fed 1 of 3 experimental corn silages harvested from the planting of 3 different seed corn hybrids from wk 4 through wk 12 postpartum. However, only 21 cows (6 primiparous and 15 multiparous) completed the 12-wk feeding study because of exhausting the supply of the experimental corn silages.

Cows were fed individually their assigned diets once a day at $0600 \mathrm{~h}$ using a Calan Super Data Ranger (American Calan Inc.) to allow for 5 to $10 \%$ refusals. The diets were fed as a TMR and contained similar 
ingredients in equal proportion, except the type of corn silage. All diets contained $63.9 \%$ forage $(24.9 \%$ alfalfa hay and $75.1 \%$ corn silage) and $36.1 \%$ concentrate (Table 1) on a DM basis. Diets were formulated to be approximately $17.5 \% \mathrm{CP}, 24.5 \%$ starch, $33.9 \% \mathrm{NDF}$, $20.1 \% \mathrm{ADF}$, and $5.6 \%$ ether extract, and were equal in estimated $\mathrm{NE}_{\mathrm{L}}$ at $1.61 \mathrm{Mcal} / \mathrm{kg}$ of $\mathrm{DM}$ with all other nutrients formulated to meet or exceed nutrient requirements according to the NRC (2001) for a cow weighing $682 \mathrm{~kg}$, producing $41 \mathrm{~kg}$ of milk with $3.7 \%$ fat and $3.1 \%$ protein. Agricultural Modeling and Training Systems software (AMTS LLC, Groton, NY) was used to formulate the TMR. Ration formulation and ingredient proportions were exactly the same among treatments except for the type or source of the experimental corn silage. Monensin and recombinant bST (Rumensin and rbST, Elanco Animal Health, Greenfield, IN) were not used in this study. Cows were milked 3 times daily at 0700, 1500, and $2200 \mathrm{~h}$ with milk production recorded electronically (Delaval-Alpro, Kansas City, MO) at each individual milking.

Body weight was electronically recorded using a digital livestock scale (model AWB-5K-SYS, Triner Scale and Manufacturing Company Inc., Olive Branch, MS) after morning milking between 0800 and $0900 \mathrm{~h}$ and BCS were taken at the end of every week including the covariate period. The BCS were recorded independently by 3 experienced individuals at the start of the study (covariate) and at the end of each week. The BCS were taken by using a scale of 1 to 5 , with 5 being obese and 1 being emaciated as described by Wildman et al. (1982) and Edmonson et al. (1989).

\section{Sample Collections}

Individual ingredients, concentrate mix, TMR, and orts samples were taken weekly, composited by month, and subsamples were submitted to 2 different commercial laboratories for analysis of nutrient concentrations. Corn silage and hay samples were checked for DM on a weekly basis, and rations were adjusted to maintain ingredients at constant DM percentages. Samples of TMR were taken weekly to measure particle size using the Penn State Particle Separator (PSPS; Kononoff et al., 2003). The amounts of particles retained on the different screens were weighed and recorded.

Milk samples were collected at all 3 milking times once weekly. Milk samples were composited on a percentage by milk yield basis and sent to Heart of America DHI laboratory (Manhattan, KS) for compositional and quality analysis using AOAC International (2016) approved methods.

Rumen fluid samples were collected via an esophageal tube fitted with a suction strainer and hand operated
Table 1. Ingredient composition of experimental diets

\begin{tabular}{|c|c|c|c|}
\hline \multirow[b]{2}{*}{ Diet ingredient } & \multicolumn{3}{|c|}{ Experimental diet ${ }^{1}$} \\
\hline & STA & $\mathrm{LF}_{1}$ & $\mathrm{LF}_{2}$ \\
\hline Starch corn silage & 48.0 & - & - \\
\hline $\mathrm{LF}_{1}$ corn silage & - & 48.0 & - \\
\hline $\mathrm{LF}_{2}$ corn silage & - & - & 48.0 \\
\hline Alfalfa hay & 15.9 & 15.9 & 15.9 \\
\hline Ground corn & 11.6 & 11.6 & 11.6 \\
\hline Soybean meal & 0.97 & 0.97 & 0.97 \\
\hline Distillers grain with solubles & 6.77 & 6.77 & 6.77 \\
\hline Corn gluten meal & 1.39 & 1.39 & 1.39 \\
\hline Whole cottonseed & 7.74 & 7.74 & 7.74 \\
\hline Blood meal & 0.35 & 0.35 & 0.35 \\
\hline $\begin{array}{l}\text { Heat-treated soybean meal } \\
\text { with lysine }\end{array}$ & 2.90 & 2.90 & 2.90 \\
\hline Rumen bypass methionine ${ }^{3}$ & 0.11 & 0.11 & 0.11 \\
\hline Rumen bypass lysine ${ }^{4}$ & 0.15 & 0.15 & 0.15 \\
\hline Urea & 0.48 & 0.48 & 0.48 \\
\hline Energy booster $100^{5}$ & 0.77 & 0.77 & 0.77 \\
\hline Limestone & 1.43 & 1.43 & 1.43 \\
\hline Sodium phosphate monohydrate & 0.23 & 0.23 & 0.23 \\
\hline Sodium bicarbonate & 0.28 & 0.28 & 0.28 \\
\hline Magnesium oxide & 0.09 & 0.09 & 0.09 \\
\hline Potassium magnesium sulfate & 0.19 & 0.19 & 0.19 \\
\hline Potassium chloride white & 0.10 & 0.10 & 0.10 \\
\hline Salt white & 0.35 & 0.35 & 0.35 \\
\hline Selenium yeast ${ }^{6}$ & 0.01 & 0.01 & 0.01 \\
\hline Mineral vitamin premix $^{7}$ & 0.19 & 0.19 & 0.19 \\
\hline Total & 100.00 & 100.00 & 100.00 \\
\hline
\end{tabular}

${ }^{1} \mathrm{STA}=$ diet with Dekalb blend corn silage (Monsanto Company, St. Louis, $\mathrm{MO}$ ); $\mathrm{LF}_{1}=$ diet with Masters Choice 527 corn silage (Masters Choice, Anna, IL); $\mathrm{LF}_{2}=$ diet with Masters Choice 5250 corn silage.

${ }^{2}$ Soybest Pearl, Grain States Soya, West Point, NE.

${ }^{3}$ Meti Pearl, Kemin Industries, Des Moines, IA.

${ }^{4}$ Lysi Pearl, Kemin Industries.

${ }^{5}$ Energy booster 100, Milk Specialties Global, Eden Prairie, MN.

${ }^{6}$ Mixture of organic selenium yeast and brewers dried yeast, Sel-Plex 2000 (Alltech Inc., Brookings, SD).

${ }^{7} 10 \%$ magnesium, $2.5 \%$ zinc, $1.9 \%$ manganese, $325 \mathrm{mg} / \mathrm{kg}$ cobalt, 5,830 $\mathrm{mg} / \mathrm{kg}$ copper, $325 \mathrm{mg} / \mathrm{kg}$ iodine, $1,515 \mathrm{mg} / \mathrm{kg}$ selenium, $544.32 \mathrm{kIU} /$ $\mathrm{kg}$ vitamin A, $186.86 \mathrm{kIU} / \mathrm{kg}$ vitamin $\mathrm{D}_{3}, 2.18 \mathrm{kIU} / \mathrm{kg}$ vitamin $\mathrm{E}$.

pump on one day during wk 3,6 , and 9 of the experimental period approximately $3 \mathrm{~h}$ after feeding. The first $100 \mathrm{~mL}$ of rumen fluid was discarded to minimize saliva contamination. After collection, rumen fluid was mixed thoroughly and $\mathrm{pH}$ was measured immediately using an electronic pH meter (Corning 350, Corning Inc., Corning, NY). If the rumen fluid collected was at a $\mathrm{pH}>7.0$, rumen fluid was discarded and additional rumen fluid was collected to ensure minimal saliva contamination. Two 10-mL samples of rumen fluid were collected, where one $10-\mathrm{mL}$ sample was added to a vial containing $200 \mu \mathrm{L}$ of $50 \%$ (vol/vol) $\mathrm{H}_{2} \mathrm{SO}_{4}$ for later determination of $\mathrm{NH}_{3}-\mathrm{N}$ and the other $10-\mathrm{mL}$ sample was added to a vial containing $2 \mathrm{~mL}$ of $25 \%$ (wt/vol) metaphosphoric acid for later determination of VFA. After sample collection and preparation, rumen fluid samples were immediately stored at $-20^{\circ} \mathrm{C}$ for further analysis. 


\section{Sample Analyses}

Feed samples (TMR, concentrate mix, and individual ingredients) were composited by month and dried at $55^{\circ} \mathrm{C}$ for $48 \mathrm{~h}$ in a forced-air oven (style V-23, Despatch Oven Co., Minneapolis, MN). Composites of feed samples were ground to a $4 \mathrm{~mm}$ particle size (Wiley mill, Arthur H. Thomas Co., Philadelphia, PA), and then further ground to a 1-mm particle size using an ultracentrifuge mill (Brinkman Instruments Co., Westbury, NY) before being sent to Analab (Fulton, IL) for $\mathrm{DM}$ and nutrient analysis. Samples were analyzed using the following AOAC International (2016) methods: DM (935.29), CP (990.03), NDF with amylase (2002.04, without sulfite), $\mathrm{ADF}$ (973.18, not in sequence), ADIN (973.18 and 976.06), neutral detergent insoluble protein (2002.04, without sulfite and 976.06), lignin (973.18), ash (942.05 and Undersander et al., 1993), Ca (985.01), $\mathrm{P}$ (985.01), Mg (985.01), K (985.01), Na (985.01), Cl (915.01), S (923.01), and $\mathrm{pH}$ (981.12). The remaining nutrients parameters were measured using the following methods: soluble protein (Krishnamoorthy et al., 1982), starch (Glucose Reagent Set, Amresco, Solon, $\mathrm{OH}$; Alpkem Corporation, Portland, OR), oil/fat (Damon, 1966), in vitro DM digestibility [24-h ruminal and 24-h enzymatic digestion using the Kansas State Buffer (Marten and Barnes, 1980)], NDF digestibility [NDFd; Van Soest et al., 1991, incubated for $30 \mathrm{~h}$ using the Kansas State Buffer (Marten and Barnes, 1980)], lactic acid (El Rassi, 1996), acetic acid (Cancalon, 1993), NFC calculated using assay results (NRC, 2001), $\mathrm{NE}_{\mathrm{L}}$ calculated from assay results including NDFd and lignin (NRC, 2001), and vomitoxin (ELISA test kit, Neogen Corporation, Lansing, MI). In addition, the DM composition of forages and grain mix was determined weekly by drying in a $105^{\circ} \mathrm{C}$ forced-air oven (Despatch LEVBI-75, Despatch Industries, Minneapolis, MN).

The monthly composites of each experimental corn silage were subsampled and submitted to Rock River Laboratory Inc. (Watertown, WI) for nutrient analyses. Samples were also analyzed for CP, soluble protein, neutral detergent insoluble crude protein, acid detergent insoluble crude protein (ADICP), available CP calculated as CP minus ADICP, NDF, fat, lignin, starch, ash, $\mathrm{pH}$, lactic acid, and acetic acid using standard AOAC International (2016) methods as described previously. However, additional analyses of undigested $\mathrm{NDF}$ at 30, 120, and $240 \mathrm{~h}$ (Raffrenato, et al., 2018), total-tract NDF digestibility (Goeser and Combs, $2009)$, dynamic NDF digestion rate $\left(\mathbf{k}_{\mathrm{d}}\right.$; Goeser and Combs, 2009), soluble starch (Akerlind, et al., 2011), 7-h in vitro starch digestion (Richards, et al., 1995), and ammonia were conducted to provide additional characterization of the experimental corn silages.
The composition of milk fat, protein, and lactose of composited milk samples were analyzed via near-infrared spectroscopy (Bentley 2000 Mid-Infrared Milk Analyzer, Bentley Instruments, Chaska, MN). The MUN concentration was determined using a chemical method based on a modified Berthelot reaction (Chaney and Marbach, 1962; ChemSpec 150 Analyzer, Bentley Instruments). Somatic cell counts were determined with a flow cytometer laser (Somacount 500, Bentley Instruments). Energy-corrected milk was calculated using the equation $[(0.327 \times \mathrm{kg}$ of milk $)+(12.95 \times \mathrm{kg}$ of fat $)+$ $(7.20 \times \mathrm{kg}$ of protein $)]$, and $3.5 \% \mathrm{FCM}$ was calculated using the equation $(0.4324 \times \mathrm{kg}$ of milk $)+(16.216 \times$ $\mathrm{kg}$ of milk fat), as described by Orth (1992).

Rumen fluid samples were thawed and centrifuged at $30,000 \times g$ for $20 \mathrm{~min}$ at $20^{\circ} \mathrm{C}$ (Eppendorf 5403, Eppendorf North America, Hauppauge, NY). Rumen fluid samples that were preserved in $50 \% \mathrm{H}_{2} \mathrm{SO}_{4}$ were analyzed for rumen $\mathrm{NH}_{3}-\mathrm{N}$ concentrations as described by Chaney and Marbach (1962) and Weatherburn (1967). Rumen fluid samples preserved in $25 \%$ metaphosphoric acid were analyzed for VFA concentrations using a gas chromatograph (model 6890, Hewlett-Packard, Palo Alto, CA) with a flame ionization detector. The injector port temperature was set at $250^{\circ} \mathrm{C}$ with an injection split ratio of $30: 1$. The VFA were separated on a capillary column $(15 \mathrm{~m} \times 0.25 \mathrm{~mm}$ i.d.; Nukol, 17926-01C, Supelco Inc., Bellefonte, PA) with a flow rate $1.3 \mathrm{~mL} / \mathrm{min}$ of He using 2-ethylbutryate as an internal standard. The column and detector temperatures were maintained at 140 and $250^{\circ} \mathrm{C}$, respectively.

\section{Statistical Analyses}

All data were checked for normality and outliers using the Univariate procedure of SAS (version 9.4, SAS Institute Inc., Cary, NC) before any statistical analyses were conducted. Box and whisker plots and the Shapiro-Wilk test were used to verify that data were normality distributed $(P>0.10)$. All data (milk production, composition, feed intake, and so on) were then subjected to least squares ANOVA for a randomized complete block design (Steele and Torrie, 1980) using the MIXED procedure of SAS having 3 corn silage dietary treatments and 7 blocks or replicates. The statistical model used was

$$
\begin{gathered}
\mathrm{Y}_{\mathrm{ijk}}=\mu+\operatorname{Rep}_{\mathrm{i}}+\mathrm{T}_{\mathrm{j}}+\mathrm{W}_{\mathrm{k}}+\left(\mathrm{T}_{\mathrm{j}} \times \mathrm{W}_{\mathrm{k}}\right) \\
+\operatorname{Cov}+\mathrm{e}_{\mathrm{ijk}},
\end{gathered}
$$

where $Y_{\mathrm{ijk}}=$ the dependent variable, $\mu=$ the overall mean, $\operatorname{Rep}_{\mathrm{i}}=$ the replication or block, $\mathrm{T}_{\mathrm{j}}=$ the treatment (experimental corn silage), $\mathrm{W}_{\mathrm{k}}=$ the study 
week, $\mathrm{T}_{\mathrm{j}} \times \mathrm{W}_{\mathrm{k}}=$ the interaction of treatment by study week, $\mathrm{Cov}=$ the covariate, and $\mathrm{e}_{\mathrm{ijk}}=$ the random error. Cows were blocked according to calving date and parity (2 primiparous vs. 5 multiparous/treatment). Due to parity being nested within Rep, it was found to be nonsignificant $(P>0.15)$ and therefore deleted from the statistical model. The individual cow data from the covariate week (3rd week postpartum) were included in the model. Treatment, week, and treatment $\times$ week interactions were considered fixed effects with Rep/ block as a random effect. Least squares covariate adjusted means were separated by the PDIFF statement. The PDIFF statement is the least significant difference method, which was used to compare treatment means when the ANOVA $F$-test was significant. The monthly composites of experimental corn silages and TMR were statistically analyzed using the PROC MIXED procedure as a completely random design having 6 observations per treatment. Treatment was considered a fixed effect in the model. All results are reported as least squares means. Differences among treatments were considered significant at $P<0.05$ and trends at $0.05<P \leq 0.10$.

\section{RESULTS AND DISCUSSION}

\section{Cropping Seasons}

The 2012 crop growing season was drier and hotter than normal, but the 2013 crop growing season was closer to normal (Table 2), when considering the historical average temperature and precipitation for the past 30 yr. Thus, the experimental corn silages harvested during the 2012 growing season $\left(\mathrm{LF}_{1}\right.$ and $\left.\mathrm{LF}_{2}\right)$ were drought stressed due to high temperatures and lack of rainfall compared with corn silage produced in the 2013 crop season (STA). The temperature and rainfall during the major corn growing months of June, July, and August was $+5.4^{\circ} \mathrm{C}$ and $-130.4 \mathrm{~mm}$ rain versus $+0.3^{\circ} \mathrm{C}$ and $14.4 \mathrm{~mm}$ rain for 2012 and 2013, respectively, compared with historical averages. Drought-stressed corn silage can be higher in $\mathrm{CP}$ and some minerals (Ca and $\mathrm{K}$ ), along with decreased energy concentrations (Roth, 2012). Corn silage potentially may have higher NDF (fiber) with a higher NDF digestibility and decreased grain (little to no starch content) depending on the drought severity (Roth, 2012). To our knowledge, side-by-side comparisons of drought-stress and non-drought-stress corn silage hybrids are not available in the literature and rations need to be balanced for nutrient availability whether drought-stress or not. The 2012 drought was among one of the most severe agricultural droughts in the history of the United States (USDA, 2013). Crop production data were not recorded because the fields were not replicated. The differences in crop growing years between corn silage hybrids was an unplanned occurrence that affected storage times between the corn silage hybrids, which could have an effect on starch digestibility (Ferraretto, 2017). The effect of storage time differences will be discussed later.

\section{Nutrient Composition of Experimental Rations}

The ingredients and their proportion used to formulate the different experimental rations are presented in Table 1. The control (STA) ration was used as the covariate diet. All experimental diets were similar in ingredient proportions and differed only in the type

Table 2. Climatic conditions during the 2012 and 2013 corn growing seasons ${ }^{1}$

\begin{tabular}{|c|c|c|c|c|}
\hline \multirow[b]{2}{*}{ Month and year } & \multicolumn{2}{|c|}{ Temperature, ${ }^{\circ} \mathrm{C}$} & \multicolumn{2}{|c|}{ Precipitation, mm } \\
\hline & Mean & Deviation $^{2}$ & Total & Deviation $^{2}$ \\
\hline April 2012 & 9.4 & 3.0 & 70.4 & 14.1 \\
\hline May 2012 & 15.6 & 2.2 & 176.3 & 96.3 \\
\hline June 2012 & 20.6 & 1.8 & 40.4 & -69.8 \\
\hline July 2012 & 25.0 & 3.7 & 35.6 & -47.6 \\
\hline August 2012 & 20.0 & -0.1 & 63.0 & -13.0 \\
\hline September 2012 & 15.0 & 0.1 & 18.5 & -61.9 \\
\hline October 2012 & 6.1 & -1.5 & 64.8 & 14.3 \\
\hline November 2012 & 0.6 & 1.4 & 11.4 & -10.8 \\
\hline April 2013 & 1.1 & -5.5 & 66.3 & 8.9 \\
\hline May 2013 & 12.8 & -0.6 & 77.5 & -4.7 \\
\hline June 2013 & 18.3 & -0.5 & 149.4 & 39.7 \\
\hline July 2013 & 21.1 & -0.3 & 91.9 & 12.3 \\
\hline August 2013 & 21.1 & 1.1 & 38.9 & -37.6 \\
\hline September 2013 & 18.3 & 3.4 & 66.8 & -11.9 \\
\hline October 2013 & 7.8 & 0.2 & 58.4 & 9.3 \\
\hline November 2013 & -1.7 & -0.9 & 10.2 & -11.0 \\
\hline
\end{tabular}

${ }^{1}$ Data collected from South Dakota State University weather station approximately $3 \mathrm{~km}$ from the fields.

${ }^{2}$ Deviation = actual minus 30-yr monthly average. 
of corn silage incorporated. Chemical composition of individual ingredients and final experimental diets are presented in Table 3. Corn silage produced from $\mathrm{LF}_{1}$ hybrid was higher in $\mathrm{CP}$ concentration compared with STA and $\mathrm{LF}_{2}$ hybrids. The vomitoxin concentration $(\mathrm{mg} / \mathrm{kg})$ was higher $(P<0.05)$ for $\mathrm{LF}_{1}$ and $\mathrm{LF}_{2}$ compared with STA silage, which might be associated with differences between the crop growing seasons (i.e., 2012 vs. 2013). The 2012 crop growing year was hotter and drier for producing the $\mathrm{LF}_{1}$ and $\mathrm{LF}_{2}$ corn silages compared with the 2013 crop growing year, which produced the control STA corn silage. Diaz et al. (2001) reported that lactating dairy cows consuming $2.5 \mathrm{mg} / \mathrm{kg}$ vomitoxin in the total ration demonstrated reduced milk production with even lower vomitoxin concentrations being implicated in reducing lactation performance. Although the goal was to balance CP concentrations at approximately $17.5 \%$, the final experimental rations were a little higher than expected. The control STA ration was approximately $0.5 \%$ lower in $\mathrm{CP}$ concentration compared with $\mathrm{LF}_{1}$ and $\mathrm{LF}_{2}$ rations, which was the result of higher $\mathrm{CP}$ concentrations of the $\mathrm{LF}_{1}$ and $\mathrm{LF}_{2}$ experimental corn silages, and the initial rations were formulated based on the STA corn silage nutrient concentrations. Ferraretto and Shaver (2015) reported that highly digestible fiber corn silage hybrids are greater in $\mathrm{CP}$ concentrations than conventional hybrids.

Total dietary NDF content was higher $(P<0.05)$ in $\mathrm{LF}_{2}$ followed by $\mathrm{LF}_{1}$ and STA. Lignin content of $\mathrm{LF}_{1}$ and $\mathrm{LF}_{2}$ diets were higher $(P<0.05)$ compared with the STA diets, which follows the trend of lignin as in silages. Starch content was higher $(P<0.05)$ in the STA diet followed by $\mathrm{LF}_{1}$ and $\mathrm{LF}_{2}$ as expected. Sugar content of $\mathrm{LF}_{1}$ and $\mathrm{LF}_{2}$ diets were higher $(P<0.05)$ compared with STA diet, due to higher sugar concentrations in the $L_{1}$ and $L_{2}$ corn silages. The NDFd was higher $(P<0.05)$ for $\mathrm{LF}_{2}$ diets compared with the STA diet, with $\mathrm{LF}_{1}$ being intermediate. Although some differences were observed between the diets in macromineral concentrations, we did not expect any variation in lactational performance because all values were close or slightly higher than mineral requirements as suggested by NRC (2001).

Chemical composition of experimental silages analyzed at a 2nd laboratory to obtain additional analytical information for silage characterization (Rock River Laboratory Inc.) reported higher $(P<0.05) \mathrm{CP}$ and available $\mathrm{CP}$ in $\mathrm{LF}_{1}$ silage, $\mathrm{LF}_{2}$ being intermediate, and STA silage being the lowest (Table 4). However, higher $(P<0.05)$ soluble protein concentrations were reported for STA corn silage compared with $\mathrm{LF}_{1}$ and $\mathrm{LF}_{2}$ silage, which is in contrast to the corn silage hybrid summary of Ferraretto and Shaver (2015). Neutral detergent insoluble crude protein was higher $(P<$
0.05) for $\mathrm{LF}_{1}$ and $\mathrm{LF}_{2}$ silage compared with STA, but ADICP was similar $(P>0.05)$ among experimental silages. The NDF content was higher $(P<0.05)$ for $\mathrm{LF}_{2}$ than $\mathrm{LF}_{1}$ but STA was intermediate. Undigestible NDF at $30 \mathrm{~h}$ was similar $(P>0.05)$ among the experimental silages. However, undigestible NDF at 120 and $240 \mathrm{~h}$ were higher $(P<0.05)$ for $\mathrm{LF}_{2}$ silage compared with STA and $\mathrm{LF}_{1}$ silage. The TTNDF and NDF $\mathrm{k}_{\mathrm{d}}$ were similar $(P>0.05)$ among the experimental silages. Total starch content was higher $(P<0.05)$ for STA silage compared with $\mathrm{LF}_{1}$ and $\mathrm{LF}_{2}$ silage as expected. Soluble starch value and 7 -h starch digestibility were higher $(P<0.05)$ for $\mathrm{LF}_{1}$ silage compared with STA with $\mathrm{LF}_{2}$ being intermediate. The greater amylopectin concentration resulting in less vitreous of the starch fractions for $L_{1}$ and $L_{2}$ would be expected to result in greater $7 \mathrm{~h}$ in vitro starch digestion (Giuberti et al., 2014; Casper et al., 2017). Nennich et al. (2003) compared conventional corn silage hybrids with 2 leafy corn silage hybrids and reported similar starch digestibility while feeding to lactating dairy cows. Ferraretto et al. (2015) also reported greater in vivo starch digestibility for leafy floury corn silage compared with BMR silage. In contrast, Morrison et al. (2014) reported similar starch digestibility for leafy starch and BMR silage diets. The other possible confounding factor to consider is that $L F_{1}$ and $L F_{2}$ silages were stored for over a year and storage time has been shown to result in increasing corn silage starch digestibility with storage time (Ferraretto, 2017). Total sugar content value was double in $\mathrm{LF}_{1}$ and $\mathrm{LF}_{2}$ silage compared with STA. Whole plant sugar concentrations were higher for $\mathrm{LF}_{1}$ and $\mathrm{LF}_{2}$ hybrids in corn silage variety trials (Kleinjan et al., 2017). However, experimental silages were similar in terms of fat, lignin, and ash content. Lactic acid concentration was higher $(P<0.05)$ in STA silage, whereas ammonia concentration was higher $(P<0.05)$ in $\mathrm{LF}_{1}$ and $\mathrm{LF}_{2}$.

\section{TMR Particle Size Distributions}

The percentage of TMR particles on the upper, middle, and lower sieve and bottom pan of the PSPS (Table 5) exhibited small, but significant differences $(P$ $<0.10$ or $P<0.05)$. Cows fed $\mathrm{LF}_{1}$ and $\mathrm{LF}_{2}$ TMR were higher $(P<0.05)$ in particles retained on the upper sieve compared with cows fed the STA TMR (Table $5)$. Since all values from PSPS screens were within the recommended ranges (Heinrichs and Kononoff, 2002; Kononoff et al., 2003) and the differences were rather small between treatments, the expectation would be that TMR particle size would not influence lactational performance due to TMR particle size variations. The data are supplied to support that conclusion. 


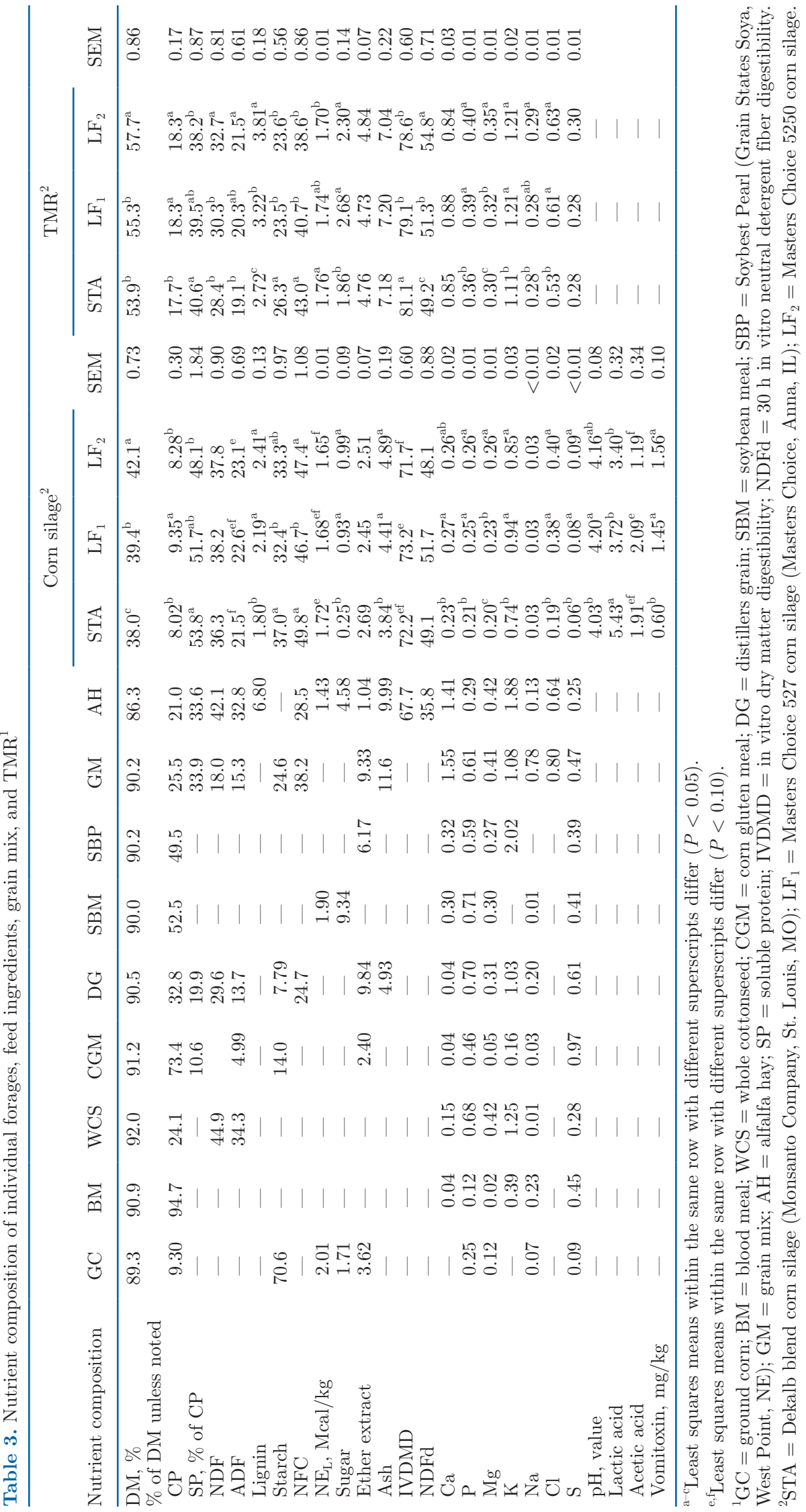


Table 4. Nutrient composition (\% of DM) of experimental corn silages ${ }^{1}$

\begin{tabular}{|c|c|c|c|c|c|}
\hline \multirow[b]{2}{*}{ Nutrient composition $^{2}$} & \multicolumn{3}{|c|}{ Experimental corn silage $^{3}$} & \multirow[b]{2}{*}{ SEM } & \multirow{2}{*}{$\begin{array}{c}P< \\
\text { Treatment }\end{array}$} \\
\hline & STA & $\mathrm{LF}_{1}$ & $\mathrm{LF}_{2}$ & & \\
\hline $\mathrm{CP}$ & $7.41^{\mathrm{c}}$ & $8.67^{\mathrm{a}}$ & $8.30^{\mathrm{b}}$ & 0.13 & 0.01 \\
\hline Available CP & $6.75^{\mathrm{c}}$ & $7.99^{\mathrm{a}}$ & $7.61^{\mathrm{b}}$ & 0.12 & 0.01 \\
\hline $\mathrm{SP}, \%$ of $\mathrm{CP}$ & $60.3^{\mathrm{a}}$ & $53.8^{\mathrm{b}}$ & $53.3^{\mathrm{b}}$ & 1.18 & 0.04 \\
\hline NDICP & $0.48^{\mathrm{b}}$ & $0.60^{\mathrm{a}}$ & $0.69^{\mathrm{a}}$ & 0.03 & 0.01 \\
\hline ADICP & 0.66 & 0.67 & 0.69 & 0.02 & 0.64 \\
\hline NDF & $38.3^{\mathrm{ab}}$ & $38.1^{\mathrm{b}}$ & $39.2^{\mathrm{a}}$ & 0.51 & 0.11 \\
\hline $\mathrm{uNDF}_{30}$ & 24.6 & 23.9 & 24.6 & 0.43 & 0.31 \\
\hline $\mathrm{uNDF}_{120}$ & $11.1^{\mathrm{b}}$ & $11.5^{\mathrm{b}}$ & $12.5^{\mathrm{a}}$ & 0.19 & 0.01 \\
\hline $\mathrm{uNDF}_{240}$ & $10.7^{\mathrm{b}}$ & $11.3^{\mathrm{b}}$ & $11.9^{\mathrm{a}}$ & 0.27 & 0.06 \\
\hline TTNDFD, $\%$ of NDF & 41.6 & 40.5 & 39.6 & 0.67 & 0.37 \\
\hline Dynamic NDF $\mathrm{k}_{\mathrm{d}}, \% / \mathrm{h}$ & 4.41 & 4.39 & 4.31 & 0.10 & 0.85 \\
\hline Starch & $35.9^{\mathrm{a}}$ & $33.7^{\mathrm{b}}$ & $33.3^{\mathrm{b}}$ & 0.63 & 0.07 \\
\hline Soluble starch, $\%$ of starch & $34.3^{\mathrm{b}}$ & $39.9^{\mathrm{a}}$ & $35.6^{\mathrm{ab}}$ & 1.62 & 0.06 \\
\hline 7-h starch digestion, $\%$ of starch & $68.4^{\mathrm{c}}$ & $77.9^{\mathrm{a}}$ & $73.0^{\mathrm{b}}$ & 1.22 & 0.01 \\
\hline Sugar & $1.06^{\mathrm{b}}$ & $2.23^{\mathrm{a}}$ & $2.07^{\mathrm{a}}$ & 0.20 & 0.02 \\
\hline Fat & 2.47 & 2.46 & 2.45 & 0.05 & 0.96 \\
\hline Lignin & 2.08 & 2.17 & 2.50 & 0.16 & 0.40 \\
\hline Ash & 4.38 & 4.54 & 4.35 & 0.08 & 0.29 \\
\hline $\mathrm{pH}$ & $4.67^{\mathrm{b}}$ & $5.17^{\mathrm{a}}$ & $5.19^{\mathrm{a}}$ & 0.06 & 0.01 \\
\hline Lactic acid & $5.23^{\mathrm{a}}$ & $2.68^{\mathrm{b}}$ & $2.36^{\mathrm{b}}$ & 0.34 & 0.01 \\
\hline Acetic acid & 2.27 & 2.64 & 2.34 & 0.22 & 0.35 \\
\hline Ammonia nitrogen & $0.07^{\mathrm{b}}$ & $0.10^{\mathrm{a}}$ & $0.09^{\mathrm{a}}$ & $<0.01$ & 0.01 \\
\hline
\end{tabular}

${ }^{a-c}$ Least squares means within the same row with different superscripts differ $(P<0.05)$.

${ }^{1}$ Rock River Laboratory Inc., Watertown, WI.

${ }^{2} \mathrm{SP}=$ soluble protein; NDICP $=$ neutral detergent fiber insoluble crude protein; ADICP $=$ acid detergent fiber insoluble crude protein; $\mathrm{uNDF}_{30}=$ undigestible neutral detergent fiber at $30 \mathrm{~h} ; \mathrm{uNDF}_{120}=$ undigestible neutral detergent fiber at $120 \mathrm{~h} ; \mathrm{uNDF}_{240}=$ undigestible neutral detergent fiber at $240 \mathrm{~h}$; TTNDFD $=$ total-tract neutral detergent fiber digestibility; $\mathrm{k}_{\mathrm{d}}=$ digestion rate.

${ }^{3} \mathrm{STA}=$ Dekalb blend corn silage (Monsanto Company, St. Louis, MO); LF $_{1}=$ Masters Choice 527 corn silage (Masters Choice, Anna, IL); $\mathrm{LF}_{2}=$ Masters Choice 5250 corn silage.

${ }^{4}$ Probability of $F$-test for treatment.

\section{DMI}

Dry matter intake was similar $(P>0.10)$ among lactating cows fed the treatment diets containing the experimental corn silages (Table 6). Correspondingly, Kuehn et al. (1999), Thomas et al. (2001), and Nennich et al. (2003) reported similar DMI between rations containing conventional and leafy corn silage hybrids.
In contrast, Clark et al. (2002) reported $0.9 \mathrm{~kg} / \mathrm{d}$ higher DMI for cows fed a ration containing a leafy hybrid corn silage compared with a conventional corn silage hybrid. Hassanat et al. (2017) also reported higher DMI when cows were fed a BMR silage-based diet compared with a conventional corn silage-based diet. Ferraretto and Shaver (2015) in their meta-analysis demonstrated that high NDF digestibility corn silage hybrids enhanced

Table 5. Total mixed ration particle size distribution (\%) as measured by Penn State Particle Size Separator (PSPS; Kononoff et al., 2003) on an as-fed basis

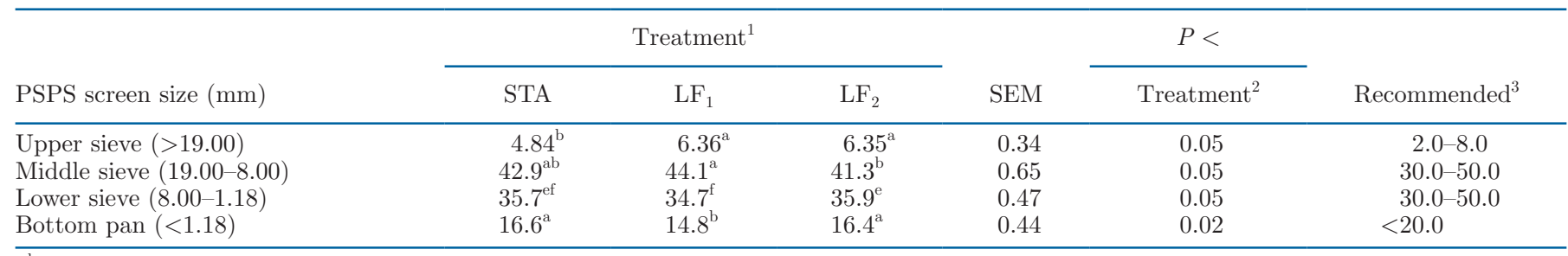

${ }^{\mathrm{a}, \mathrm{b}}$ Least squares means within the same row with different superscripts $\operatorname{differ}(P<0.05)$.

e,f Least squares means within the same row with different superscripts differ $(P<0.10)$.

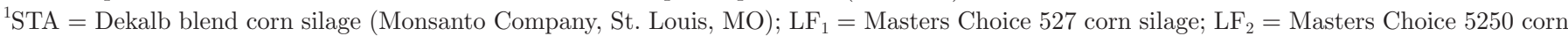
silage.

${ }^{2}$ Probability of $F$-test for treatment.

${ }^{3}$ Adapted from Heinrichs and Kononoff (2002). 
Table 6. Intake of DMI, NDF, digestible NDF, starch, corn silage starch, and ruminal degradable corn silage starch intake by early-lactation dairy cows fed TMR differing in corn silage hybrids

\begin{tabular}{|c|c|c|c|c|c|}
\hline Measurement & \multicolumn{3}{|c|}{ Treatment $^{1}$} & SEM & $\begin{array}{c}P< \\
\text { Treatment }^{2}\end{array}$ \\
\hline DMI, $\mathrm{kg} / \mathrm{d}$ & 22.9 & 23.5 & 22.4 & 0.78 & 0.46 \\
\hline NDF intake, $\mathrm{kg} / \mathrm{d}$ & $6.44^{\mathrm{b}}$ & $7.13^{\mathrm{a}}$ & $7.30^{\mathrm{a}}$ & 0.35 & 0.03 \\
\hline NDF intake, $\%$ of BW & $0.99^{\mathrm{b}}$ & $1.10^{\mathrm{a}}$ & $1.12^{\mathrm{a}}$ & 0.04 & 0.04 \\
\hline Digestible NDF intake, ${ }^{3} \mathrm{~kg} / \mathrm{d}$ & $3.17^{\mathrm{b}}$ & $3.66^{\mathrm{a}}$ & $4.00^{\mathrm{a}}$ & 0.06 & 0.01 \\
\hline Starch intake, \% of BW & $0.92^{\mathrm{a}}$ & $0.86^{\mathrm{b}}$ & $0.81^{\mathrm{b}}$ & 0.03 & 0.07 \\
\hline Corn silage starch intake, $\mathrm{kg} / \mathrm{d}$ & $4.07^{\mathrm{a}}$ & $3.56^{\mathrm{b}}$ & $3.40^{\mathrm{b}}$ & 0.17 & 0.01 \\
\hline Corn silage starch intake, \% of BW & $0.63^{\mathrm{a}}$ & $0.55^{\mathrm{b}}$ & $0.52^{\mathrm{b}}$ & 0.02 & 0.01 \\
\hline Corn silage ruminal degradable starch intake, ${ }^{3} \mathrm{~kg} / \mathrm{d}$ & $2.78^{\mathrm{a}}$ & $2.78^{\mathrm{a}}$ & $2.48^{\mathrm{b}}$ & 0.13 & 0.13 \\
\hline Corn silage ruminal degradable starch intake, ${ }^{3} \%$ of BW & $0.43^{\mathrm{a}}$ & $0.43^{\mathrm{a}}$ & $0.38^{\mathrm{b}}$ & 0.01 & 0.04 \\
\hline
\end{tabular}

${ }^{\mathrm{a}, \mathrm{b}}$ Least squares means within the same row with different superscripts differ $(P<0.05)$.

${ }^{1} \mathrm{STA}=$ Dekalb blend corn silage (Monsanto Company, St. Louis, MO); LF $_{1}=$ Masters Choice 527 corn silage (Masters Choice, Anna, IL); LF 2 $=$ Masters Choice 5250 corn silage.

${ }^{2}$ Probability of $F$-test for treatment.

${ }^{3}$ Nutrient concentration $\times$ in vitro digestibility $\times$ DMI expressed as $\mathrm{kg} / \mathrm{d}$ or $\%$ of $\mathrm{BW}$.

DMI compared with conventional corn silage hybrids. Calculations of NDF intake and digestible NDF (NDF $\times \mathrm{NDFd})$ intake as $\mathrm{kg} / \mathrm{d}$ and $\%$ of $\mathrm{BW}$ demonstrated that cows fed $\mathrm{LF}_{1}$ and $\mathrm{LF}_{2}$ consumed more $(P<0.05)$ digestible fiber than cows fed STA. It is possible that gut fill could be limiting DMI for cows fed $L_{1}$ and $\mathrm{LF}_{2}$ compared with cows fed STA. In contrast, cows fed STA consumed more $(P<0.05)$ starch intake as $\mathrm{kg} / \mathrm{d}$ and $\%$ of BW compared with cows fed $\mathrm{LF}_{1}$ and $\mathrm{LF}_{2}$. Thus, cows fed $\mathrm{LF}_{1}$ and $\mathrm{LF}_{2}$ consume more digestible fiber than cows fed STA, whereas cows fed STA consumed more starch. The 7 -h starch digestibility was only conducted on the experimental corn silages and not the entire TMR; therefore, calculations are based only on the corn silage contribution to the ration (Table 1). This calculation would eliminate or ignore the corn starch contribution, which was similar across all experimental diets. The amount of corn silage starch was greater $(P<0.05)$ for cows fed STA compared with cows fed $\mathrm{LF}_{1}$ and $\mathrm{LF}_{2}$; however, the amount of rumen degradable starch coming from corn silage was similar $(P>0.10)$ for cows fed STA and $\mathrm{LF}_{1}$, which was greater $(P<0.05)$ when compared with cows fed $\mathrm{LF}_{2}$ when expressed as $\mathrm{kg} / \mathrm{d}$ or $\%$ of BW. These data demonstrate that similar amounts of ruminal degradable starch can be achieved with a lower corn silage starch concentration that is more ruminally digestible. Mertens (2016) suggested a total NDF intake of $1.25 \%$ of BW can maximize forage intake, while meeting the energy requirements of the lactating dairy cow. Grant et al. (2018) reported that increasing undigestible $\mathrm{NDF}$ as a $\%$ of DM resulted in a linear decreased in DMI. In contrast, calculating undigestible NDF at 240 $\mathrm{h}$ as a percentage of $\mathrm{BW}$ resulted in concentrations of $0.38,0.41$, and $0.41 \%$ of $\mathrm{BW}$, respectively, which would indicate that the amount of indigestible NDF may be limiting intake, but more work is needed in this area (Mertens, 2016). The goal for maximizing nutrient intake would be through combining increased ruminal starch digestion with increased ruminal NDF digestion.

\section{Milk Production and Composition}

Production of milk, 3.5\% FCM, and ECM was similar $(P>0.10)$ among dairy cows fed the 3 treatments containing experimental corn silages (Table 7). Kuehn et al. (1999), Ballard et al. (2001), and Nennich et al. (2003) also reported similar milk yields when conventional and leafy corn silage hybrids were fed to lactating dairy cows. However, Thomas et al. (2001) and Clark et al. (2002) reported greater milk yields by cows fed diets containing leafy corn silage hybrids than cows fed conventional hybrids. Hassanat et al. (2017) reported higher milk yield, $4 \%$ FCM yield, and ECM yield when cows were fed BMR corn silage instead of conventional corn silage. A meta-analysis by Ferraretto and Shaver (2015) reported an increase of $1.0 \mathrm{~kg} / \mathrm{d}$ of milk production for cows fed highly digestible fiber corn silage hybrids compared with conventional corn hybrids, but $3.5 \%$ FCM yields were similar. This increase in milk production was similar to the increase in milk production when feeding BMR corn silage, which indicates that both types of corn silage hybrids are enhancing milk production via increased fiber (NDF) digestibility. The concern with the literature to date is these corn silage hybrid lactation studies have not been conducted 
Table 7. Yield of milk, 3.5\% FCM and ECM, milk composition, MUN, feed efficiency (FE), BW, and BCS by early-lactation dairy cows fed TMR differing in corn silage hybrids

\begin{tabular}{|c|c|c|c|c|c|}
\hline \multirow[b]{2}{*}{ Measurement } & \multicolumn{3}{|c|}{ Treatment $^{1}$} & \multirow[b]{2}{*}{ SEM } & \multirow{2}{*}{$\begin{array}{c}P< \\
\text { Treatment }^{2}\end{array}$} \\
\hline & STA & $\mathrm{LF}_{1}$ & $\mathrm{LF}_{2}$ & & \\
\hline Lactating cows, no. & 7 & 7 & 7 & - & - \\
\hline Milk, kg/d & 35.6 & 34.8 & 36.1 & 1.18 & 0.63 \\
\hline Fat, $\%$ & 4.17 & 3.94 & 3.71 & 0.21 & 0.30 \\
\hline Fat yield, $\mathrm{kg} / \mathrm{d}$ & 1.47 & 1.36 & 1.34 & 0.57 & 0.14 \\
\hline Protein, $\%$ & 3.12 & 3.09 & 3.03 & 0.08 & 0.61 \\
\hline Protein yield, $\mathrm{kg} / \mathrm{d}$ & 1.12 & 1.07 & 1.10 & 0.06 & 0.74 \\
\hline $\mathrm{SCC}, 10^{5}$ cells $/ \mathrm{mL}$ & 4.57 & 4.75 & 4.64 & 0.16 & 0.62 \\
\hline Lactose, $\%$ & 4.93 & 4.92 & 4.92 & 0.04 & 0.95 \\
\hline SNF, $\%$ & 8.96 & 8.92 & 8.85 & 0.07 & 0.31 \\
\hline MUN, mg/dL & $13.6^{\mathrm{b}}$ & $15.0^{\mathrm{a}}$ & $15.0^{\mathrm{a}}$ & 0.54 & 0.02 \\
\hline $3.5 \% \mathrm{FCM}^{3}{ }^{3} \mathrm{~kg} / \mathrm{d}$ & 38.7 & 36.5 & 37.6 & 1.41 & 0.16 \\
\hline $\mathrm{ECM},{ }^{4} \mathrm{~kg} / \mathrm{d}$ & 38.2 & 36.1 & 38.1 & 1.42 & 0.16 \\
\hline BW change, $\mathrm{kg} / \mathrm{d}$ & -0.10 & -0.06 & -0.08 & 0.04 & 0.48 \\
\hline Average BW, kg & 646.7 & 647.7 & 647.8 & 7.95 & 0.98 \\
\hline BCS change/d & -0.05 & -0.04 & -0.05 & 0.04 & 0.71 \\
\hline FE, milk/DMI & 1.60 & 1.52 & 1.68 & 0.08 & 0.22 \\
\hline $3.5 \%$ FCM FE & 1.79 & 1.61 & 1.67 & 0.07 & 0.19 \\
\hline \multicolumn{6}{|c|}{$\overline{\mathrm{a}, \mathrm{b}}$ Least squares means within the same row with different superscripts differ $(P<0.05)$} \\
\hline $\begin{array}{l}{ }^{1} \mathrm{STA}=\text { Dekalb blen } \\
\text { (Masters Choice, An } \\
{ }^{2} \text { Probability of } F \text {-tes } \\
{ }^{3} 3.5 \% \text { FCM }=(0.432\end{array}$ & $+(16.2$ & at yield) & $\mathrm{MO}) ; \mathrm{LI}$ & Masters & ce 527 corn sil \\
\hline
\end{tabular}

on nutrient availability and digestibility basis, but only by hybrid comparisons. Casper and Mertens (2007), in their summary of more than $40 \mathrm{yr}$ of energy metabolism studies, demonstrated that digestibility was the biggest factor limiting energy intake by the lactating dairy cow and the major factor in ration digestibility would be forage fiber digestibility

Milk fat and milk protein percentages were similar $(P>0.10)$ among all treatments. In addition, milk fat and milk protein yields $(\mathrm{kg} / \mathrm{d})$ were similar $(P>$ $0.10)$ among treatments. Nennich et al. (2003) reported similar percentages and yields of milk fat and protein when lactating dairy cows were fed conventional and leafy corn silage hybrids. In contrast, Thomas et al. (2001) reported a trend toward greater protein yield from cows fed a leafy corn silage hybrid diet. Clark et al. (2002) reported a $0.05 \mathrm{~kg} / \mathrm{d}$ increase in milk fat production for cows fed a leafy corn silage hybrid ration compared with a ration containing conventional corn silage hybrids. Kuehn et al. (1999), Bal et al. (2000), Ballard et al. (2001), and Nennich et al. (2003) reported no improvement in FCM yield from feeding leafy corn silage hybrids over conventional corn silage hybrids, whereas Thomas et al. (2001) and Clark et al. (2002) reported an increase in FCM yield, while feeding leafy corn silage hybrids over conventional corn silage hybrids. Hassanat et al. (2017) reported lower milk fat $\%$ and MUN but higher milk fat yield, protein yield, and lactose yield when BMR silage was fed compared with conventional corn silage.

Percentages of lactose and SNF, along with SCC, were similar $(P>0.10)$ for early-lactation dairy cows fed all treatments. Similar milk SCC were reported by Nennich et al. (2003) when conventional and leafy corn silage hybrids were fed to lactating dairy cows. Hassanat et al. (2017) reported similar lactose \% and SCC, but higher lactose yield when BMR silage was fed compared with conventional corn silage. Ferraretto and Shaver (2015) reported similar lactose and protein concentrations and yields among many different types of corn silage hybrids. If corn silage hybrid was going to affect milk composition, the major effect would be on milk fat concentrations followed by milk protein in contrast to other milk components.

Milk urea nitrogen was lower $(P<0.05)$ for cows fed a ration containing STA corn silage compared with cows fed a ration containing $\mathrm{LF}_{1}$ and $\mathrm{LF}_{2}$ corn silage, which followed the higher starch and lower CP concentration of the STA corn silage. Since the STA diet has about $0.5 \%$ lower $\mathrm{CP}$ and more starch compared with $\mathrm{LF}_{1}$ and $\mathrm{LF}_{2}$ diets, we were expecting lower MUN in STA than $\mathrm{LF}_{1}$ and $\mathrm{LF}_{2}$ diets. Hassanat et al. (2017) reported lower MUN when fed BMR silage compared with conventional corn silage. However, Ferraretto and Shaver (2015) reported that greater NDF digestibility resulted in lower MUN due to more ammonia being 
incorporated into microbial protein. In contrast, this study is confounded by both lower $\mathrm{CP}$ and greater NDF and starch digestibilities, which may make drawing specific conclusion(s) speculative.

\section{$B W$ and BCS}

Body weight, BCS, and change in BW and BCS were similar $(P>0.05)$ among treatments (Table 7$)$ during the 9-wk, early-lactation study. The early-lactation cows would be expected to be losing BW and BCS during this period of the lactation. Cows in this study were losing less BW than reported by Holt et al. (2013), but our milk production was slightly lower. Given the similar milk production, milk composition, BW, and BCS changes would indicate that all rations were similar in energy concentrations and digestibility. However, given the differences in nutrient concentrations and intake (Tables 3, 4, and 6), a greater portion of the digestible energy was being supplied by starch for cows fed STA rations compared with digestible fiber and fast starch digestion (greater 7 -h starch digestion) for cows fed $\mathrm{LF}_{1}$ and $\mathrm{LF}_{2}$ rations.

\section{Ruminal pH, Ammonia, and VFA}

Ruminal $\mathrm{pH}$ was lower $(P<0.05)$ for cows fed STA compared with cows fed $\mathrm{LF}_{1}$ and $\mathrm{LF}_{2}$ corn silage rations (Table 8). The high starch concentration of the STA ration would be expected to lower ruminal $\mathrm{pH}$ compared with a higher fiber rations of cows fed $\mathrm{LF}_{1}$ and $\mathrm{LF}_{2}$. Lower ruminal $\mathrm{pH}$ was reported by Cherney et al.
(2004) when cows were fed BMR and conventional corn hybrid silage compared with leafy hybrid corn silage, which would be the result of greater ruminal digestion of fiber and starch. In their summary across several different corn silage hybrids, no differences in ruminal $\mathrm{pH}$ were observed (Ferraretto and Shaver, 2015).

Rumen $\mathrm{NH}_{3}$ concentrations were similar $(P>0.10)$ among all experimental corn silage rations. Total VFA concentrations $(\mathrm{mmol})$ were higher $(P<0.05)$ for cows fed the STA ration compared with cows fed the $\mathrm{LF}_{1}$ ration, but similar $(P>0.10)$ and intermediate for cows fed the $\mathrm{LF}_{2}$ ration. Acetate molar concentrations were greater $(P<0.05)$ for lactating cows fed $\mathrm{LF}_{1}$ and $\mathrm{LF}_{2}$ rations compared with cows fed the STA ration, as would be expected due to the greater NDF concentrations and greater NDF digestibility of $\mathrm{LF}_{1}$ and $\mathrm{LF}_{2}$ corn silage. In contrast, cows fed the STA ration demonstrated greater $(P<0.05)$ molar concentrations of propionate compared with cows fed the $\mathrm{LF}_{1}$ and $\mathrm{LF}_{2}$ rations. The higher starch and lower NDF concentrations in the STA corn silage would be expected to shift ruminal fermentation to higher propionate and lower acetate molar concentrations. The shifts in ruminal fermentation resulted in the acetate to propionate and acetate plus butyrate to propionate ratios being greater $(P<0.05)$ for cows fed $\mathrm{LF}_{1}$ and $\mathrm{LF}_{2}$ rations compared with cows fed the STA ration. The molar concentration of isovalerate was greater $(P<0.05)$ for cows fed the STA ration compared with the cows fed $\mathrm{LF}_{2}$ diet, with cows fed the $L_{1}$ ration being similar $(P>0.10)$ and intermediate. The remaining VFA of isobutyrate, butyrate, and valerate were similar $(P>0.05)$ among

Table 8. Ruminal pH, ammonia, and VFA concentrations from early-lactation dairy cows fed different corn silage hybrids

\begin{tabular}{|c|c|c|c|c|c|}
\hline \multirow[b]{2}{*}{ Measurement } & \multicolumn{3}{|c|}{ Treatment $^{1}$} & \multirow[b]{2}{*}{ SEM } & \multirow{2}{*}{$\frac{P<}{\text { Treatment }^{2}}$} \\
\hline & STA & $\mathrm{LF}_{1}$ & $\mathrm{LF}_{2}$ & & \\
\hline Lactating cows, no. & 7 & 7 & 7 & - & - \\
\hline & $6.31^{\mathrm{c}}$ & $6.69^{\mathrm{a}}$ & $6.50^{\mathrm{b}}$ & 0.08 & 0.01 \\
\hline $\mathrm{NH}_{3}-\mathrm{N}, \mathrm{mg} / \mathrm{dL}$ & 8.60 & 9.30 & 10.3 & 0.96 & 0.30 \\
\hline $\begin{array}{l}\text { Total VFA, mmol/L } \\
\mathrm{mmol} / 100 \mathrm{mmol} \text { of total VFA }\end{array}$ & $91.8^{\mathrm{a}}$ & $72.3^{\mathrm{b}}$ & $86.5^{\mathrm{ab}}$ & 6.21 & 0.10 \\
\hline Acetate & $59.5^{\mathrm{b}}$ & $63.8^{\mathrm{a}}$ & $62.4^{\mathrm{a}}$ & 0.95 & 0.02 \\
\hline Propionate & $26.1^{\mathrm{a}}$ & $21.0^{\mathrm{b}}$ & $23.1^{\mathrm{b}}$ & 0.87 & 0.01 \\
\hline Isobutyrate & 0.58 & 0.59 & 0.55 & 0.05 & 0.80 \\
\hline Butyrate & 10.9 & 11.9 & 11.3 & 0.57 & 0.47 \\
\hline Isovalerate & $1.35^{\mathrm{a}}$ & $1.09^{\mathrm{ab}}$ & $1.00^{\mathrm{b}}$ & 0.13 & 0.15 \\
\hline Valerate & $\begin{array}{l}1.00 \\
1.63\end{array}$ & 1.67 & 1.64 & 0.09 & 0.95 \\
\hline Acetate:propionate & $2.32^{\mathrm{b}}$ & $3.10^{\mathrm{a}}$ & $2.81^{\mathrm{a}}$ & 0.12 & 0.01 \\
\hline Acetate + butyrate:propionate & $2.74^{\mathrm{b}}$ & $3.67^{\mathrm{a}}$ & $3.32^{\mathrm{a}}$ & 0.14 & 0.01 \\
\hline
\end{tabular}

${ }^{a-c}$ Least squares means within the same row with different superscripts differ $(P<0.05)$.

${ }^{1} \mathrm{STA}=\mathrm{TMR}$ with Dekalb blend corn silage (Monsanto Company, St. Louis, MO); $\mathrm{LF}_{1}=\mathrm{TMR}$ with Masters Choice 527 corn silage (Masters Choice, Anna, IL); $\mathrm{LF}_{2}=\mathrm{TMR}$ with Masters Choice 5250 corn silage.

${ }^{2}$ Probability of $F$-test for treatment. 
treatments. Holt et al. (2013) fed conventional corn silage or BMR corn silage with high-quality alfalfa hay to early-lactation dairy cows and reported similar ruminal $\mathrm{pH}$, total VFA, acetate, propionate, butyrate, and acetate:propionate ratio among cows fed conventional or BMR corn silage. Hassanat et al. (2017) also fed conventional or BMR corn silage and reported similar ruminal $\mathrm{pH}$, total VFA, acetate, propionate, and butyrate but lower ruminal $\mathrm{NH}_{3}$ concentration while feeding BMR corn silage. However, Oba and Allen (2000), Taylor and Allen (2005), and Gorniak et al. (2014) reported reduced mean ruminal $\mathrm{pH}$ when feeding BMR corn silage compared with conventional corn silage, which would be related to enhanced BMR corn silage nutrient digestibility. Ferraretto and Shaver (2015) in their meta-analysis reported that several different corn silage hybrids resulted in similar concentrations of ruminal ammonia, total VFA, and individual VFA concentrations. If rumen health is being maintained (i.e., cud chewing, ruminal $\mathrm{pH}$, saliva production, passage rates, and so on), then corn silage hybrid may have little effect on VFA concentrations, even though total microbial and VFA production is being increased (i.e., $\mathrm{g} / \mathrm{d})$.

\section{CONCLUSIONS}

Seed corn hybrid selection is an important management decision for corn silage production to economically feed lactating dairy cows. New corn hybrids are introduced every year that could vary greatly in nutrient digestibility, so it is essential to evaluate their lactational response using energy-demanding early-lactation dairy cows. This study demonstrated that $\mathrm{CP}$ of $\mathrm{LF}_{1}$ corn silage was higher than $\mathrm{LF}_{2}$ and STA corn silage, whereas the starch content was higher for STA corn silage. The digestible NDF per unit of DM was lower for STA compared with $\mathrm{LF}_{1}$ and $\mathrm{LF}_{2}$ (14.0, 15.5, and $17.9 \% \mathrm{DM}$, respectively) corn silages, which implies that the $L_{1}$ and $\mathrm{LF}_{2}$ hybrids are supplying more digestible fiber. The growing season can affect vomitoxin concentrations in corn silage, which may have influenced lactational performance of the $\mathrm{LF}_{1}$ and $\mathrm{LF}_{2}$ hybrids. However, the similar DMI, milk production, and composition among hybrids demonstrate that feeding a lower starch, but higher digestible fiber, corn silage ration can support milk production compared with a higher starch, lower digestible NDF ration. The future of enhancing lactational performance would be to enhance both fiber and starch concentrations and digestibility to increase nutrient supply to early-lactation dairy cows without lowering $\mathrm{pH}$, while increasing acetate and propionate production and microbial synthesis.

\section{ACKNOWLEDGMENTS}

The authors thank Masters Choice (Anna, IL) for donation of leafy-floury corn seeds and partial funding of this project. The donation by Agri-King Inc. (Fulton, IL) of the Silo-King and Grain States Soya of Soybest is greatly appreciated. The authors express appreciation to the South Dakota State University Dairy Research and Training Facility staff for the care of the dairy animals, and D. Casper's Dairy Science Production graduate students (South Dakota State University, Brookings) for assistance in feeding, sample collection, and laboratory analyses. The authors declared no conflicts of interest.

\section{REFERENCES}

Akerlind, M., M. Wisbjerg, T. Eriksson, R. Togersen, P. Uden, B. L. Olafsson, O. M. Harstad, and H. Volden. 2011. Feed analyses and digestion methods. NorFor-The Nordic feed evaluation system. H. Volden, ed. EAAP-European Federation of Animal Science. Vol. 30. Wageningen Academic Publishers, Wageningen, the Netherlands. https://doi.org/10.3920/978-90-8686-718-9_5.

AOAC International. 2016. Official Methods of Analysis. 20th ed. AOAC Int., Gaithersburg, MD.

Bal, M. A., R. D. Shaver, H. Al-Jobeile, J. G. Coors, and J. G. Lauer. 2000. Corn silage hybrid effects on intake, digestion, and milk production by dairy cows. J. Dairy Sci. 83:2849-2858. https://doi .org/10.3168/jds.S0022-0302(00)75185-X.

Ballard, C. S., E. D. Thomas, D. S. Tsang, P. Mandebvu, C. J. Sniffen, M. I. Endres, and M. P. Carter. 2001. Effect of corn silage hybrid on dry matter yield, nutrient composition, in vitro digestion, intake by dairy heifers, and milk production by dairy cows. J. Dairy Sci. 84:442-452. https://doi.org/10.3168/jds.S0022-0302(01)74494 -3 .

Barriere, Y., J. C. Emile, R. Traineau, and Y. Hebert. 1995. Genetic variation in the feeding efficiency of maize genotypes evaluated from experiments with dairy cows. Plant Breed. 114:144-148. https://doi.org/10.1111/j.1439-0523.1995.tb00779.x.

Cancalon, P. F. 1993. Rapid monitoring of fruit juice adulteration by capillary electrophoresis. Liquid Chromatography Gas Chromatography 11:748-751.

Casper, D. P., and D. R. Mertens. 2007. Feed efficiency of lactating dairy cows is related to dietary energy density. J. Dairy Sci. 90(Suppl. 1):407. (Abstr.)

Casper, D. P., S. Srivastava, and B. Strayer. 2017. Feeding a calf starter containing highly digestible corn may improve calf growth. Transl. Anim. Sci. 1:343-350. https://doi.org/tas2017.0041.

Chaney, A. L., and E. P. Marbach. 1962. Modified reagents for determination of urea and ammonia. Clin. Chem. 8:130-132. https:// doi.org/10.1093/clinchem/8.2.130.

Cherney, D. J. R., J. H. Cherney, L. E. Chase, and W. J. Cox. 2004. Milk production in high producing dairy cows as influenced by corn silage quality. Prof. Anim. Sci. 20:302-311. https://doi.org/ 10.15232/S1080-7446(15)31319-X.

Clark, P. W., S. Kelm, and M. I. Endres. 2002. Effect of feeding a corn hybrid selected for leafiness as silage or grain to lactating dairy cattle. J. Dairy Sci. 85:607-612. https://doi.org/10.3168/jds.S0022 -0302(02)74114-3.

Diaz, D. E., W. M. Hagler, Jr, B. A. Hopkins, R. A. Patton, C. Brownie, and L. W. Whitlow. 2001. The effect of inclusion of a clay type sequestering agent on milk production of dairy cattle consuming mycotoxins contaminated feeds. J. Dairy Sci. 84:1554 (Abstr.)

Damon, C. 1966. Hawk's Physiological Chemistry. 14th ed. McGrawHill, New York, NY. 
Edmonson, A. J., I. J. Lean, L. D. Weaver, T. Farver, and G. Webster. 1989. A body condition scoring chart for Holstein dairy cows. J. Dairy Sci. 72:68-78. https://doi.org/10.3168/jds.S0022 -0302(89)79081-0.

El Rassi, Z. 1996. High Performance Capillary Electrophoresis of Carbohydrates. Beckman Instruments Inc., Fullerton, CA

Ferraretto, L. F. 2017. Impact of starch content and digestibility in dairy cattle diets. Pages 112-123 in Proc. 28th Florida Ruminant Nutrition Symposium, Gainesville, FL.

Ferraretto, L. F., A. C. Fonseca, C. J. Sniffen, A. Formigoni, and R. D. Shaver. 2015. Effect of corn silage hybrids differing in starch and neutral detergent fiber digestibility on lactation performance and total-tract nutrient digestibility by dairy cows. J. Dairy Sci. 98:395-405. https://doi.org/10.3168/jds.2014-8232.

Ferraretto, L. F., and R. D. Shaver. 2015. Effects of whole-plant corn silage hybrid type on intake, digestion, ruminal fermentation, and lactation performance by dairy cows through a meta-analysis. J. Dairy Sci. 98:2662-2675. https://doi.org/10.3168/jds.2014-9045.

Giuberti, G., A. Gallo, F. Masoero, L. F. Ferraretto, P. C. Hoffman, and R. D. Shaver. 2014. Factors affecting starch utilization in large animal food production systems: A review. Starch 66:72-90. https: //doi.org/10.1002/star.201300177.

Goeser, J. P., and D. K. Combs. 2009. An alternative method to assess 24-h ruminal in vitro neutral detergent fiber digestibility. J. Dairy Sci. 92:3833-3841. https://doi.org/10.3168/jds.2008-1136.

Gorniak, T., U. Meyer, F. Hackelsperger, and S. Dänicke. 2014. Effects of a brown-midrib corn hybrid on nutrient digestibility in wethers and on dry matter intake, performance, rumen and blood variables in dairy cows. J. Anim. Physiol. Anim. Nutr. (Berl.) 98:300-309. https://doi.org/10.1111/jpn.12080.

Grant, R., W. Smith, M. Milller, K. Ishida, and A. Obata. 2018. A tale of two fibers: Optimizing peNDF and uNDF. Pages 1-5 Proc. Dairy Day at Miner Institute.

Hassanat, F., R. Gervais, and C. Benchaar. 2017. Methane production, ruminal fermentation characteristics, nutrient digestibility, nitrogen excretion, and milk production of dairy cows fed conventional or brown midrib corn silage. J. Dairy Sci. 100:2625-2636. https:// doi.org/10.3168/jds.2016-11862.

Heinrichs, J., and P. Kononoff. 2002. Evaluating particle size of forages and TMRs using the new Penn State Forage Particle Separator. DAS 02-42. Pennsylvania State University, University Park, PA.

Holt, M. S., J. S. Eun, C. R. Thacker, A. J. Young, X. Dai, and K. E. Nestor Jr. 2013. Effects of feeding brown midrib corn silage with a high dietary concentration of alfalfa hay on lactational performance of Holstein dairy cows for the first 180 days of lactation. J. Dairy Sci. 96:515-523. https://doi.org/10.3168/jds.2012-5856.

Kleinjan, J., D. Casper, K. K. Kirby, and S. M. Hawks. 2017. Corn silage variety trial archive. South Dakota State University. Open Prairie: Open public research access institutional repository and information exchange. Accessed Apr. 4, 2019. https://openprairie.sdstate .edu/cgi/viewcontent.cgi?article=1012\&context=extension_pubs.

Kononoff, P. J., A. J. Heinrichs, and D. R. Buckmaster. 2003. Modification of the Penn State forage and total mixed ration particle separator and effects of moisture content on its measurements. J. Dairy Sci. 86:1858-1863. https://doi.org/10.3168/jds.S0022 $-0302(03) 73773-4$.

Krishnamoorthy, U., T. V. Muscato, C. J. Sniffen, and P. J. Van Soest. 1982. Nitrogen fractions in selected feedstuffs. J. Dairy Sci. 65:217-225. https://doi.org/10.3168/jds.S0022-0302(82)82180-2.

Kuehn, C. S., J. G. Linn, D. G. Johnson, H. G. Jung, and M. I. Endres. 1999. Effect of feeding silages from corn hybrids selected for leafiness or grain to lactating dairy cattle. J. Dairy Sci. 82:27462755. https://doi.org/10.3168/jds.S0022-0302(99)75531-1.

Marten, G. C., and R. F. Barnes. 1980. Prediction of energy digestibility of forages with in vitro rumen fermentation and fungal enzyme systems. Pages 61-71 in Standardization of Analytical Methodology for Feeds: Proceedings of a Worship held in Ottawa, Canada. March 12-14, 1979, IDRC, Ottawa, Canada.

Mertens, D. R. 2016. Measuring and using uNDF to improve dairy nutrition. 2016 Southwest Nutr. Conf. Feb. 17-19, Tempe, AZ.

Morrison, S. Y., K. Cotanch, C. Ballard, H. Dann, E. Young, R. Grant, and C. Key. 2014. Lactational response of Holstein cows to brown midrib or leafy-floury corn silage. J. Dairy Sci. 97(Suppl.1):533. (Abstr.)

Nennich, T. D., J. G. Linn, D. G. Johnson, M. I. Endres, and H. G. Jung. 2003. Comparison of feeding corn silages from leafy or conventional corn hybrids to lactating dairy cows. J. Dairy Sci. 86:2932-2939. https://doi.org/10.3168/jds.S0022-0302(03)73890 $-9$.

NRC. 2001. Nutrient Requirements of Dairy Cattle. 7th rev. ed. Natl. Acad. Sci., Washington, DC.

Oba, M., and M. S. Allen. 1999. Effects of brown midrib 3 mutation in corn silage on dry matter intake and productivity of high yielding dairy cows. J. Dairy Sci. 82:135-142. https://doi.org/10.3168/jds .S0022-0302(99)75217-3.

Oba, M., and M. S. Allen. 2000. Effects of brown midrib 3 mutation in corn silage on productivity of dairy cows fed two concentrations of dietary neutral detergent fiber: 1 . Feeding behavior and nutrient utilization. J. Dairy Sci. 83:1333-1341. https://doi.org/10.3168/ jds.S0022-0302(00)75000-4.

Orth, R. 1992. Sample day and lactation report. DHIA 200 Fact Sheet A-2. Mid-States DRPC, Ames, IA.

Raffrenato, E., R. Fievisohn, K. W. Cotanch, R. J. Grant, L. E. Chase, and M. E. Van Amburgh. 2017. Effect of lignin linkages with other plant cell wall components on in vitro and in vivo neutral detergent fiber digestibility and rate of digestion of grass forages. J. Dairy Sci. 100:8119-8131. https://doi.org/10.3168/jds.2016-12364.

Raffrenato, E., D. A. Ross, and M. E. Van Amburgh. 2018. Development of an in vitro method to determine rumen undigested aNDFom for use in feed evaluation. J. Dairy Sci. 101:9888-9900. https: //doi.org/10.3168/jds.2018-15101.

Richards, C. J., J. F. Peterson, R. B. Britton, R. A. Stock, and C. R. Krehbiel. 1995. In vitro starch disappearance procedure modifications. Anim. Feed Sci. Technol. 68:25-35. https://doi.org/10.1016/ 0377-8401(95)00790-T

Roth, G. R. 2012. Managing drought stressed corn. Accessed Jan. 12, 2020. https://extension.psu.edu/managing-drought-stressed-corn.

Steele, R. G. D., and J. H. Torrie. 1980. Principles and Procedures of Statistics. 2nd ed. McGraw-Hill Book Co., New York, NY.

Taylor, C. C., and M. S. Allen. 2005. Corn grain endosperm type and brown midrib 3 corn silage: Ruminal fermentation and N partitioning in lactating cows. J. Dairy Sci. 88:1434-1442. https://doi .org/10.3168/jds.S0022-0302(05)72811-3.

Thomas, E. D., P. Mandebvu, C. S. Ballard, C. J. Sniffen, M. P. Carter, and J. Beck. 2001. Comparison of corn silage hybrids for yield, nutrient composition, in vitro digestibility, and milk yield by dairy cows. J. Dairy Sci. 84:2217-2226. https://doi.org/10.3168/ jds.S0022-0302(01)74668-1.

Undersander, D. J., W. T. Howard, and R. D. Shaver. 1993. Milk per acre spreadsheet for combining yield and quality into a single term. J. Prod. Agric. 6:231-235. https://doi.org/10.2134/jpa1993 .0231 .

USDA. 2013. Crop Production 2012. National Agricultural Statistics Service, Washington, DC.

Van Soest, P. J., J. B. Robertson, and B. A. Lewis. 1991. Methods for dietary fiber, neutral detergent fiber, and nonstarch polysaccharides in relation to animal nutrition. J. Dairy Sci. 74:3583-3597. https://doi.org/10.3168/jds.S0022-0302(91)78551-2.

Weatherburn, M. W. 1967. Phenol-hypochlorite reaction for determinations of ammonia. Anal. Chem. 39:971-974. https://doi.org/10 $.1021 /$ ac60252a045.

Wildman, E. E., G. M. Jones, P. E. Wagner, R. L. Boman, H. F. Troutt Jr., and T. N. Lesch. 1982. A dairy cow body condition scoring system and its relationship to standard production characteristics. J. Dairy Sci. 65:495-501. https://doi.org/10.3168/jds .S0022-0302(82)82223-6.

\section{ORCIDS}

David P. Casper (1) https://orcid.org/0000-0002-0666-8808 